\title{
Агеева Е.A.
}

\section{Театральная элита Великобритании в период Второй мировой войны: модель социально-политического поведения (по материалам англоязычной печати)}

\author{
Ageeva E.A. \\ The Great Britain theater elite during World War II: \\ social and political behaviour patterns of conduct \\ (according to English-language newspapers)
}

Анализируются особенности творческой и социально-политической деятельности театральной элиты британского общества в чрезвычайных условиях военного времени, ее представления и ценностные ориентации. Рассматривается реализация идеологических, пропагандистских и воспитательных целей. Делается вывод о том, что развитие массовых форм досуга способствовали консолидации социума

Ключевые слова: интеллектуальная элита, пресса, гуманизм, досуг и развлечения гражданского населения, театральное искусство

Агеева Елена Андреевна

Кандидат исторических наук, доцент Финансовый университет при Правительстве РФ 2. Москва, Ленинградский $п р-m, 49$
The author analyzes the specifics of social and political behaviour and system of values of the Great Britain theater elite during the war time. This research is focused on the achievement ideological, propagandist and educational objectives. The author makes the conclusion that the development of the mass leisure activities in Great Britain contributed to the consolidation of the society

Key words: intellectual elite, press, humanism, civilians' leisure and recreation, theatre

\section{Ageeva Elena Andreevna}

Candidate of Historical Sciences, Associate Professor Financial university under the Government of the $R F$ Moscow, Leningradsky ave., 49

О военно-политических событиях Второй мировой войны написано много работ. В настоящее время особую актуальность приобретает исследование неполитических факторов развития, таких как социальные способы сплочения нации, условия реализации творческой личности, возможности организации досуга гражданского населения в чрезвычайных условиях военного времени.

Война преобразила духовную жизнь общества, социальные институты, систему ценностей, этические и эстетические нормы. Война потребовала также перестройки всех учреждений культуры. На первый план выдвинулись наиболее оперативные, мобильные, доступные и эффективные формы культурной работы - радио, кинематограф, периодическая печать. 
Британская пресса, традиционно игравшая огромную роль в жизни общества, стала транслятором патриотического движения, рупором антифашистских идей, выполняла функцию обратной связи между правительством и обществом, между народом и творческой интеллигенцией. «The Times» была «царицей газетного мира», её аудиторию составляла политическая, финансовая элита, творческая интеллигенция, широкие народные массы.

Творческая интеллигенция, как наиболее рефлексирующая часть общества, оказалась втянутой в военно-политические события, в идеологическую полемику, в агитационную деятельность. Некоторые представители театрально - литературной среды английского общества, например, драматург Джон Пристли, прошли окопы Первой мировой войны, испытав на себе все ужасы того времени. Другие - литератор Уистон Оден - воевали в Испании. Писатель, сценарист Кристофер Ишервуд лично наблюдал события в Германии, приведшие к власти Гитлера.

Мировые войны разрушали «башню из слоновой кости», в которой на рубеже XIX-XX вв. прибывала российская и большая часть западной интеллигенции. В данном случае под этим выражением понимается «самодостаточность творческой личности, ...последовательное дистанцирование интеллигентов как от власти, так и от народа...» [4, с. 17]. Знамением времени стала возрастающая роль социально-политического фактора в жизни искусства, подобные мотивы стали неизбежными, а в период Второй мировой войны зачастую и преобладающими.

Театр Великобритании в полной мере испытал на себе специфику и тяготы военного времени, а интеллектуальная элита получила новые цели, творческие возможности и мотивацию. После вступления Великобритании в войну 3 сентября 1939 года все развлекательные заведения были закрыты. Для страны, имеющий многовековые театральные традиции и круглогодичный театральный сезон, это было невероятным событием. Через некоторое время театры, концертные залы, кинозалы вновь давали спектакли, демонстрировали представления и кинофильмы. Правительство объяснило этот шаг необходимостью избавить население от возможной апатии, связанной с войной, а также задачей приобщения людей к искусству. В феврале 1941 правительственные органы даже разрешили устраивать воскресные представления, несмотря на религиозные ограничения. Подобным актом правительство показывало, как высоко оценивается вклад искусства в военные усилия нации.

В качестве основных задач театральной и, вообще, художественной деятельности, стали идеологические, пропагандистские и воспитательные задачи. Как отмечал публицист Генрих Ансельм, «война против нацисткой Германии не была обычной войной, это был конфликт идеологий, который после «немецкой трепки» Первой мировой войны перерос в борьбу за защиту цивилизованного мира от фашистского варварства. Британия боролась за свое культурное наследие, <> искусство стало необходимым средством, чтобы напомнить стране, за что она борется» [2, с. 62-63]

Общественные, государственные деятели, люди искусства обнаружили невероятную для мирного времени связь между репертуаром театров и ростом 
боевого духа британцев. Постановка шекспировской драмы - не менее значительный вклад в победу, чем операции армии и флота. Гамлет Джона Гилгуда и Гамлет Лоренса Оливье стали для английской публики не только возрождением классики, традиций отечественной театральной школы, но и мощным средством сплочения нации, укрепления ее самосознания и воли.

Особенно значительную роль в укреплении духовных традиций английской нации сыграл некоммерческий, репертуарный театр «Олд Вик». Художественные руководители театра ставили перед труппой задачи бескорыстного служения искусству и просвещения народа. Подобная система ценностей привлекала в театр наиболее интеллигентную часть публики и лучших актеров, которые готовы были поступиться меркантильными интересами и высокими гонорарами ради чести играть в «Олд Вик». Известная английская актриса Эдит Эванс в зените популярности покинула подмостки Вест_Энда, гарантировавшего высокие гонорары и согласилась на скромное жалованье с единственной целью сыграть классические роли, особенно героинь У. Шекспира. Об этих и других работах театра почти в каждом номере писала «Таймс» [7].

Герберт Маршалл, ученик С.Эйзенштейна, незадолго до войны из любительской труппы создал театр «Юнити», участниками спектаклей которого были главным образом рабочие и творческая молодежь. Когда начались бомбардировки Лондона, театр за двое суток подготовил политическое обозрение «Дурацкие мешки с песком». Этой и другими постановками театр заработал себе репутацию пропагандистской сцены [3, с. 11].

От творческой интеллигенции была и практическая польза обществу. Например, июньский 1941 года номер «Таймс» сообщал, что в Вигмор-холле Джен Норис давала сольный фортепианный концерт в поддержку фонда защиты от воздушных налетов, учрежденного мэром [5]. Ассоциация, организующая отдых военнослужащих, E.N.S.A., со штаб-квартирой в лондонском театре «Друри-Лейн» в самом начале войны взяла на себя невиданную ранее задачу отправлять профессиональные гастрольные труппы в гарнизоны и военные учебные центры Британии, а также в экспедиционные войска [3, c. 12].

Боевой дух нации, жизненный оптимизм и энтузиазм в работе поддерживало не только классическое искусство. Коммерческий, развлекающий публику Вест-Энд, по существу, делал ту же работу, только иными методами и средствами. В военное время в театральной афише Лондона и других городов широко был представлен «легкий» жанр. В британской музыке были свои штраусы и кальманы. Уильям Гильберт и Артур Салливан - английские композиторы, создавшие во второй половине XIX века четырнадцать «комических опер». Все оперы Гильберта и Салливана были впервые поставлены в театре «Савой» и поэтому получили название «Савойских опер». В военное время режиссер театра «Савой» Долей Карт решил вернуть на сцену оперу «Гандольеры» А.Салливана, написанную в далеком 1889 году. Как писала «Таймс», подобная опереточная буффонада должна была «показать Гитлеру и его союзникам, что Лондон остается собой, лондонцы не теряют присутствия духа и готовы получать удовольствие от искусства даже после напряженного рабочего дня». И для заядлых 
театралов, и для новичков спектакль стал «оазисом в пустыне напряженных дней и темных ночей» [6].

Театральное искусство в военное время нужно обществу в первую очередь для поддержки духа и воли народа. Зритель в тяжелое время войны нуждался в высоком классическом искусстве, в гуманистическом содержании шекспировских драм. Но, может быть, еще в большей степени он нуждался в реализации гедонистической и компенсаторной функций искусства, в повышении общего жизненного тонуса, в утешении, преодолении социальной апатии, в восстановлении сил и повышении уровня оптимизма.

Британское правительство, содействуя развитию художественной культуры и театра в особенности, преследовало и другие цели: сохранение художественной сферы жизни общества, поддержку статуса Великобритании на международной арене. Лондон - не только мировой деловой центр, но и культурная столица Европы. Это обстоятельство было особенно важным, если учитывать, что другая культурная столица - Париж - была оккупирована немцами. Национальная гордость британцев всегда была мощным духовным фактором развития общества.

Индустрия развлечений была необходимой составляющей жизни британского социума, несмотря на тяготы и лишения военного времени. Интеллектуальная элита английского общества своей творческой деятельностью способствовала развитию института потребления, в первую очередь, естественно, духовного. В условиях войны и связанных с ней катаклизмов эта сфера общественной деятельности приобретала характер так называемой «общественной роскоши», которая ценилась не меньше, чем английские виски, тонкие шерстяные ткани и фаянс [1, с.203]. Это еще раз подтверждало тот факт, что духовное, творческое начало может быть определяющим в развитии нации.

\section{Список используемых источников:}

1. Агеева Е.А., Четвергова В.К. Социально-экономическая политика Британского правительства и массовые формы досуга гражданского населения в период Второй мировой войны // Академический вестник ТГАМЭУП №1 (31). Тюмень: Тюменская государственная академия мировой экономики, управления и права, 2015. С. 199-209.

2. Ансельм Г. Театр в Британии во время Второй мировой войны // New Theatre Quarterly. T. 26. Bып. 1. 2010. С. 61-70.

3. Дьюкс Э.Репертуарные и камерные театры во времена войны // Britain To-day. 1940. № 34. P. 9-12. 4. Интеллигенция и интеллектуалы в изменяющейся социально-политической действительности. Иваново, 2014.

5. Музыка на этой неделе. Возвращение Оперы // The Times. 1941. № 49.959. 22 июня.

6. Театр «Савой». Гандольеры // The Times. 1941. № 49.950. 12 июня.

7. Театры. Новые постановки и возобновления // The Times. 1941. № 49.941. 2 июня.

(C) 2016, Агеева E.A.

Театральная элита Великобритании в период Второй мировой войны: модель социальнополитического поведения (по материалам англоязычной печати)
(C) 2016, Ageeva E.A.

The Great Britain theater elite during World War II: social and political behaviour patterns of conduct (according to English-language newspapers) 